\title{
S ABCD-4170
}

ICS ALANOS SCIBNTIFIC LABORATORY

of

THE UNIVERSITY OF CALIFORNIA

Sept ember 25, 1950

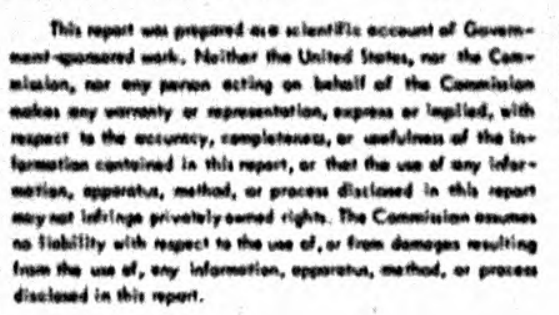

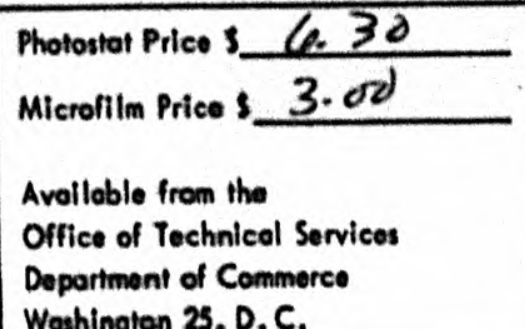

THE PREPARATION AND PHYSICAL PROPERTIES OF URANIUA BINARY NLLOYS CONTAINING ALURININM AND COLNRBIUS

by

D. W. Grobecker, W. F. Arnold

J. M. Taub and D. T. Doll

URANIUM TECHNOLOGY

$1-2$ 


\section{ABSTRACT}

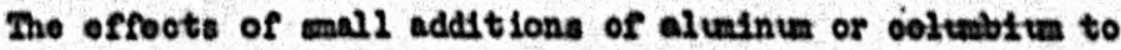
uranium woro investigated in ordor to find or alloy addition agent which would oubstentially incroase the ylold otrongth an: oroop rosiotanco of uranium. Tho use of aluninum as an addition agon, was flrot Investigated, but early work indicated tho use of al uninum to be impractical. The ocaposition of the aluminum-uranilu alloy was diffioult to control, and the physical proporties of the as-oast alloys wero oxtromoly orratio. The reaponse of the aluminum alloy to solution treatment and aging was inconsistent and the struotures obtained wore vaprodictable. Although oonsidorablo molting difiloulitios wore oncountered during the Inveatigation of the rraniun-00lumblum alloye, the physical properties of the as-cast alloys wro found to bo considorably superior to unalloyed uranium, and the ylold atrongthe of tho columbium alloys co uld bo furthor elovated by hoat treatment.

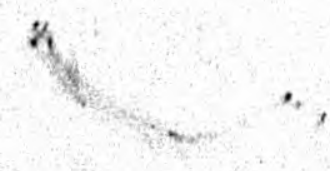




\section{IETRODUCTION}

Exporimento wore oonduoted to dotormino an alloy edditicn acont for urealiu vileh would oubstentially increase the glold otrongth and oroep rosistance of uranl um.

In additlon $1 \mathrm{t}$ was ro-

quilrod that the sollowing apoolsioations be mots

1. The alloy and a hoat treatmont, if required, were to bo devoloped in the shortest possiblo timo.

3. Alloying additions wore to be hold to a minimim and wore not to exoeod fivo atomis percent.

4. Duotility and oorroolon rosistanoo wore to bo malntainod Withln roasonablo limitio

6. It was necessary that the alloy be adaptablo to produot1on molting tochniquos.

Rosults of LAtorature Soarche.

Provious roports on urenlin alloy arateme wire studied to dotomine the alloying constituonte most $11 \mathrm{kely}$ to ralse the tonsilo propertios of uranilus. Fran tho proliminary ourvoy uranilum-aluminum alloye appoared to offor the most prent so. Work roported by Gorden (1), Bussand and Cloaves (3) Indloatod that tho uranilu woh uraniumaliminum alloys wro age hardonablo. Tho $10 \mathrm{w}$ alloy ocntent renges of 
the urani um-columblum eyeten wore Indlonted by the work of Oroninger (5) and saryor (4) to be worthy of rurther Investigation. Tho litorature soarch also indloated that binary alloys of uranium with muganove, chronilum, or platinum would poselbly glold elovated tensilo propertles. Bxoopt for one molt of 2.5 atomilo peroent manganese whloh was extromoly brittle in the as-oast oohdition, the lattor three systems wore not invostigatod.

Outline of Investigation Prooedures.

The invertigaticas woro oarriod out as sollows!

1. The flrst alloy hoats were cast to form throe ono-half inch dlemeter by three Inch long bars. The top of one bar and the bottom of anothor fran oach molt were machinod and the ohips analyzed to ahook composition and indioato homogenity. The bars wre soetlonod Into one-half inch lengths for hardnoss doterminations and photonlerographio otudles of tho as-cast condition and subsequent to a variety of heat troatanonts.

2. Whon hardnoss dotorminations Indicatod a oonposition or a heat troatment whlch ylelded Interesting propertios, standard 0.505 Inch tonsile bars were oast for tensilo studios.

3. Then a hoated and quonched bar ylolded moro dosirable propert1os then ab-cast bars of the sores oomposition, Janiny ond quonoh tests wore porformod to indicato the offoctivo dopth of quonoh. 
4. The relativo atmoopherle corrosion resistance of the alloye was detorainod by observation of the machined surfaces of tost bars aftor prolonged exposuro to alr.

5. As a finnl ohook on tho desirability of a partioular alloy or hoat troatmont oreop tests were performed.

Tho uranium-aluninum aystem, which, at the beginning of the program, was thought to bo tho most promlaing, was invostigated first. When oufriolont data had beon collooted to Indioato that tho uranliumaluminum alloys wore not desirable, the investigation of this systom was droppod ocnplotoly and the invostigation of uranlum-columbium alloys undortalcon.

Equipmont and Matorials Uood

Most of the alloy metale wore mado using Amos high purity urantum oontalning approxdmately $60 \mathrm{ppm}$ of carbon. However, somo motals wo mado with nomal uranlum contalning 300-500 ppm of carbon. When Interesting propertles wore disolosed in alloys made of normal urani im, oimilar oompositions wore mado with high purity motal to verify the rosults.

Wolts wore made in induotion heated vaouum furnaces with prossures varying betwoen 10-1000 mlercas of meroury. Tho alloys, exoopt for a fow spooinal molts noted lator, wore moltod in magnesia oruolblos with magnesia stoppor rods and poured into alumina or magnosia linod graphito molds to minimize contamination. 
High temperature heating $\left(740^{\circ} \mathrm{C}-1050^{\circ} \mathrm{C}\right)$ sor hoat treatIng was accouplished by supporting tho ploce with platinum wiro in a salt bath of NaCl or a mixt ure of twonty wight percent IfaCl, 25 poroent KCI and 65 peroent $\mathrm{BaCl}_{2}$. Tho salt was hoated in a graphito orudiblo in an induction rumace. The temperature of tho bath could be olosoly regulated by menual control of the mattage input to the Induot1on oo11. Quenching was done in a water bath with a delay betwoen. the salt bath and the quonoh tank of 1-5 soconds. Aging and low temperature hoating (up to $600^{\circ} \mathrm{C}$ ) wero dono in an Induotion hoated vaour un annealing furnaco.

Melting tomperatures wero determined by means of a Loods and Northrup Optical Pyraneter, Catalog No. 8266C. The tomperature roadings were taken on the motal by viowing through a pyrex alght glase in the rumace top. Salt bath heat treating temperatures wore dotorminod by means of a chromel-alunel themoeouplo immersed in the calt. Temperatures for the low tomperature vaouum treatment s were dotormined by a chronol-alumel themooouple placed noxt to the p1000 within the vaourn rurnaco.

Tensile detenainations were mado on standard 0.505 inch diametor tost bars using a southwark- Bnory testing machino with a maxImun loading capacity of 120,000 pounds. The tensillo spooimen a wore loaded at the rato of 1200 pounds per minute. In most oases the tonallo data show that the ratio of stress to strain was not ooneistent ovor a measurable range. The yleld strength was deteminod by a 0.2 
poroent offset lino parallel to an approximated modulus 2 ino.

Rocen tomperature croop tosts wre oonduoted on standard 0.505 Inch tonsile bars statically loaded for poriods varying from 300 to 2000 hours. In general, tho loading timo was limited to 300 hours, as provious oroop tost results on nomeal uranium bars showed that tho slopes of the timo-0longation plot obtainod during the f1rst 300 hours was Indicative of the slope of the plot up to 2000 hours, 800 F/6. 1.

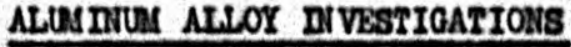

A total of fourtoon molte were mado in whioh aluninum, varyIng from 0.1 to 4.0 atomlo peroont, was the alloying element. Although Inoreased hardness and olevatod tensilo propertios were obtained fram these al loys in both the as-oast and heat treated oonditions (as ocmpared with unalloyed uranlim), the varlations in motal struoture and tonsilo results indicated that uranium-aluminum alloys, as obtainod during this program, were not suitable for production applioations. Oranium-Aluminum Alloy Molting Problems

The dosirod ocmposition of aluminum in the alloy was diffioult to achieve. Loss of al uminim die to volatilization during the molting caused deviations from the caloulated alloy ocatent which oould not be determinod readily. Exporienco showed that variations in moltIng time, temperature, or pressure gave alloys whose aluninum oontent oould not be predicted. The necessity for preolso control of these variables was a disadvantage from the practical aspeot of produotion 
ITRAT ve. THO CUNES

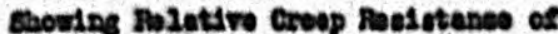

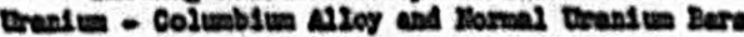

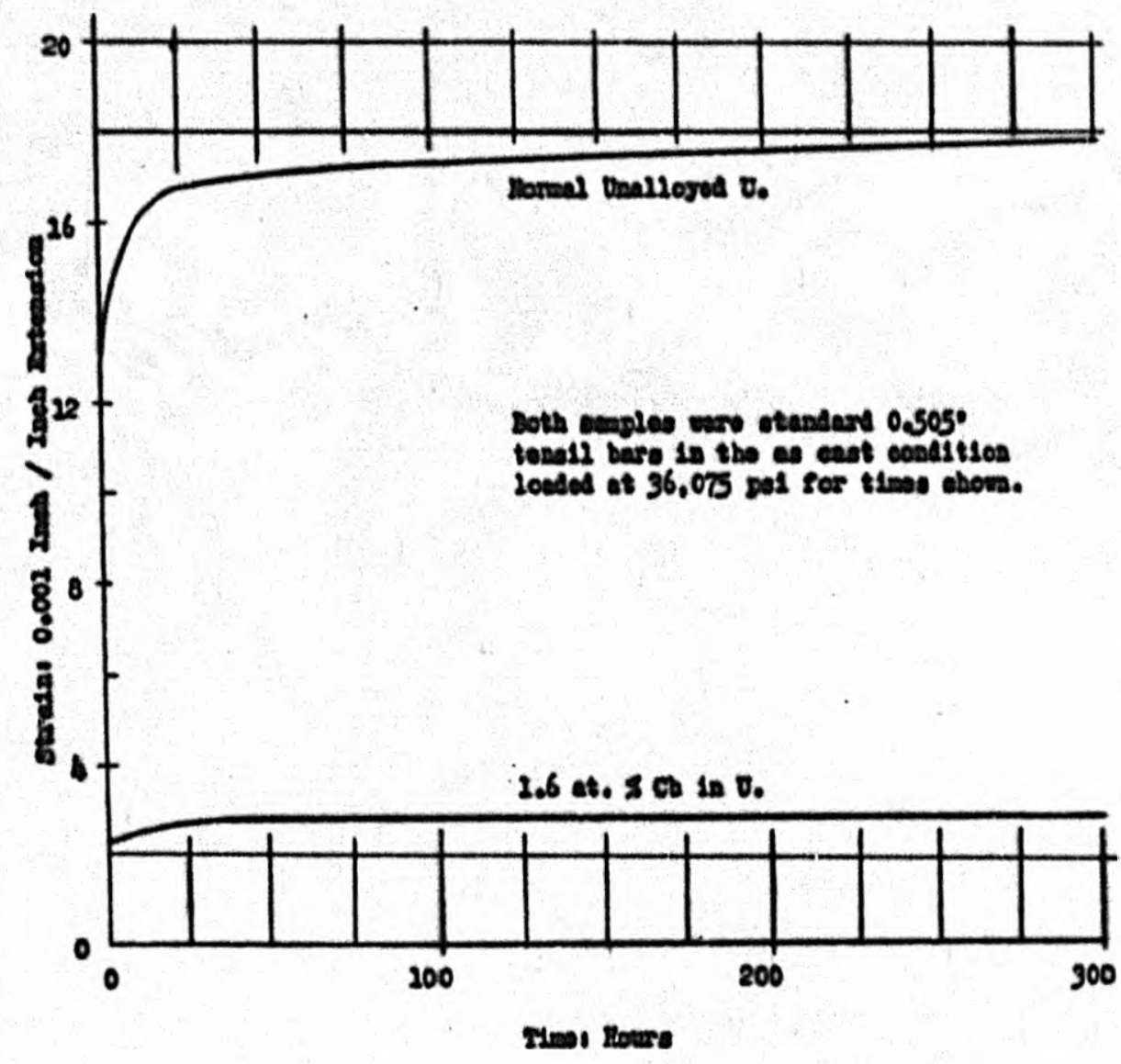

7.9. 24

9

$340 \quad 008$ 
work. It was folt that aluninum losses oould bo botter controllod by molting undor a coitrolled proseuro of inert gas to minimise aluminum volatillsaticn. This was not attomptod as later work disolosed the aluninum alloys to be generally undeal rablo.

samples taken from the top and bottcan of oach oasting genorally thowed a vido spread in aluminum oontent indleating inocompleto hanogenisation, and no oonsistent trend of eogregation in the oastings was noted. To oite ono case, a 2.5 atcmic percent aluminum alloy was desired. The chargo was mado up for a 3.5 arcanio peroent additt on of alunlnum. The alloy was molted, hold betwoen $1250-1280^{\circ} \mathrm{C}$ for fiftoen minutes at a prossure of 300-500 miorons of moroury, and poured at $1280^{\circ} \mathrm{c}$. A casting was obtainod whioh analyzod 1,64 atomio peroent aluminum at the top and 2.38 atomio peroent aluminim at tho bottomo Then molting alloys containing 2.5 atomis poroent or greator wnounts of aluminum, a reaction ooourrod aftor molt domn. This reaction has beon roportod by N. P. Allon (5) for alloys contalning greater than 5 woight peroent (31.7 atcanlo poroent) aluminum in uranium as oocurring with considerable Flolence, ovolution of heat, and spattering of metal. Although epattoring of motal was nover observod in the more diluto alloys moltod in this program, the roaction oaused surfiolent ly vigorous agitation in a number of ho ats, charged to giold a 2.5 atconio perdent aluninum alloy, that the stopper rod was dislodged with a promat ure pour rosulting. 
Heat Freating Proeedures for Urani uen-Aluninum Alloy

It was relt that solution heat treatenent followed by controllod preolpitation of the $\mathrm{UL}_{2}$ phase would be requalred to achleve the maxdmum advantage of tho alloy addition. In the paper by Oordan (1), a solution troatment of $2 \frac{1}{2}$ atoniso poroent al uninum alloy at $1040^{\circ} \mathrm{C}$, followed by a water quench, was roported to have rotuined canplote solution of the $\mathrm{DA}_{2}$ phaso. A number of bars of tho low al uninuan ascast alloy wore given a hoat troathent wiloh consioted of a soluti on troatmont at 1000 or $1050^{\circ} \mathrm{C}$ rollowed by a water quonoh. Troatmont at thi a tomperature proved impractioal rran a production vlompoint for the following roagonst

1. There was oonsids rable varlanee in hardnous between different samples of the samo analyals after 1dontioul trestmonts and al so consldorablo hardness rarlanoo botwoen adjacent indentations on the saroe plooe.

2. Photoniorographio studies showed mat appoarod to be quenoh oraoks subsequent to the treatrnent. For an example seo Figure 2.

3. The alloy at these temperatures was sem1-plast10 and doformation of a oast shape oould be expectod to rosult.

4. Oxidation of the motal was high.

5. Quenching control of oast shapes would bo diffioult from temperatures above $1000^{\circ} \mathrm{C}$.

In vlow of tho diffioulties experienced by solution treatment abovo $1000^{\circ} \mathrm{C}$, treatement at lower temperat ares within the garme- 


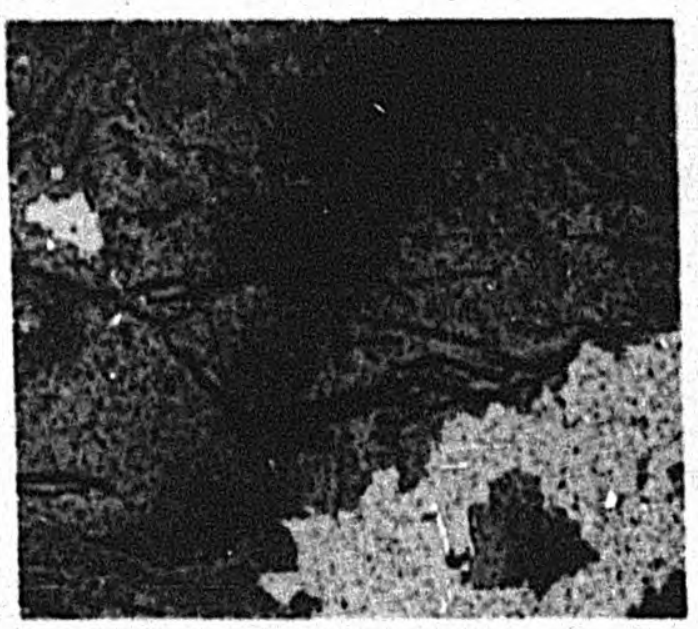

Figure 21 This 100X photomiorograph shows a 1.0 atomio percent aluminum alloy which had been heated to $1000^{\circ} \mathrm{C}$ for two hours and water quenched. The oracks shown are belleved to be caused by the abrupt quench. The craoks severely affected the ductility of the alloy and furtiner work on solution treatmo nt of aluminum alloys at this temperature was abandoned as impractical. 
uranium tomperature range was investigated. Oranium-aluminum alloys containing fran 0.9 to 3.6 atomio peroent aluminum wore solution treated at 800,850 or $900^{\circ} \mathrm{C}$ for from one-quarter to four hours at temperature. The hardnoss values, taloon ecross the face of oach $1 / 2$ Inch diemoter solution troated and quenohed tost slug, wero vory orratice. The values varied as much as 11 polnts Rookwell $\mathrm{C}$ with average deviotion from the medien value of 2 pointe Rockwoll C. The areraged hardnoss values of each hoat troated alloy pioce, when plottod as hardnoss rersus time at temperature, wre also highly orratio and railod to indiouto any hardnose tronds. Figure 3 is inoluded as an examplo of the inconsistent hardnosses resulting from the solution treatmont of uranium-aluminum alloys within the gamme-uranium tomperature range. Bocause of the inconsistent hardnosses obtained by the solution heat treatumat, afing of these alloys was not attemptod.

The solld solubilities of aluminum in uradium are roported to bo 0.82 atomilo peroent aluminum at $640^{\circ} \mathrm{C}$ in the alphe phase and 1.23 atomic peroent at the betangame transformation (4). These values indioated that the investigation of solution treatment within the beteruranium range, followed by lower tomperature aging in the alpha range might be worthy of investigation. Solution treatment of alloy speoimens containing 0.5 to 2.5 atomilo poroent aluminum at $740^{\circ} \mathrm{C} \operatorname{cor} 1 / 2$ to 4 hours at temporature, followed by a water quenoh, ylolded alightly Inoreased and ocmparatively consistont hardnosses as shown in Figure it Aging at $350^{\circ} \mathrm{C}$ subsegiont to the beta range troatenent fallod to materially 


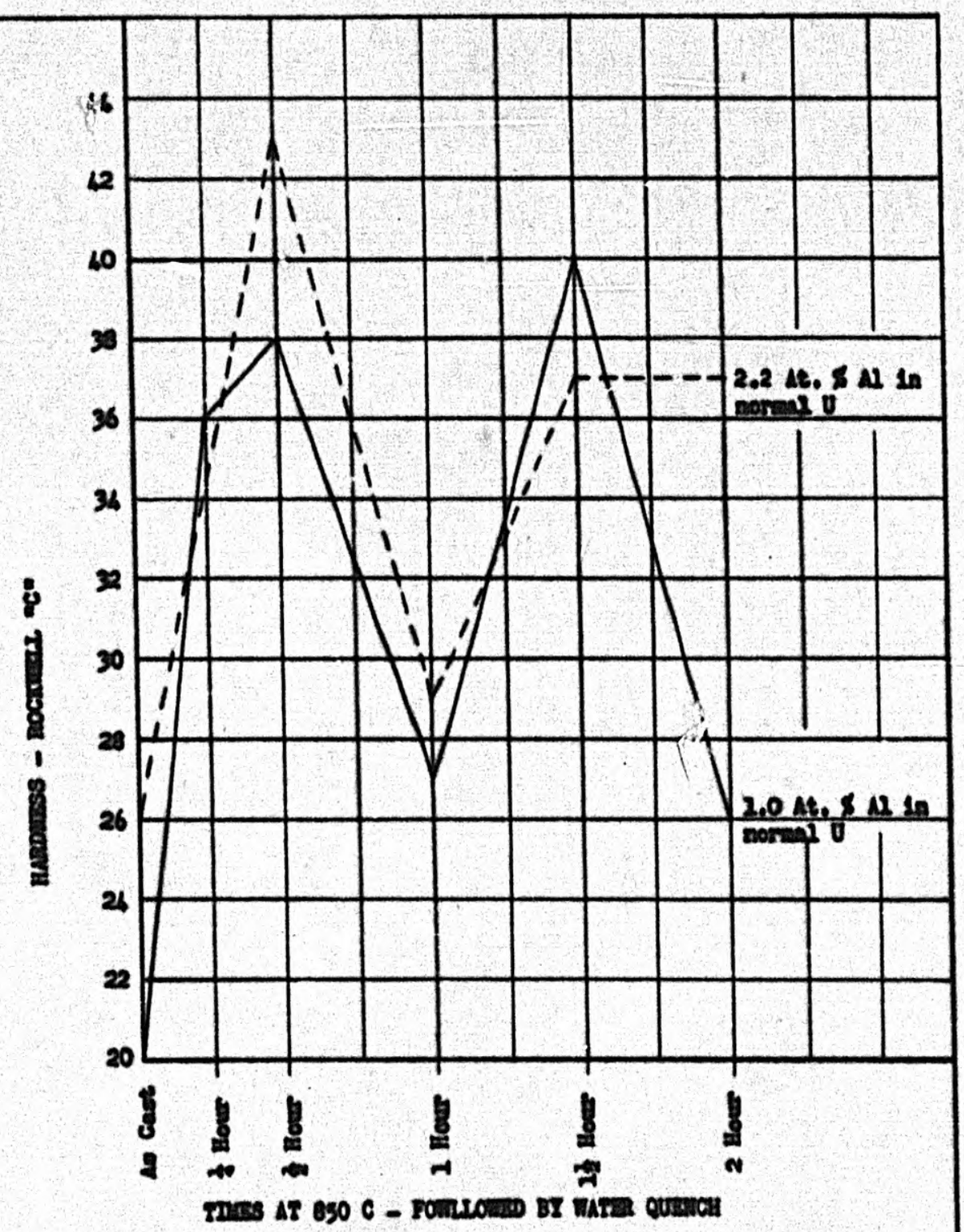

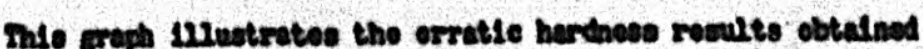

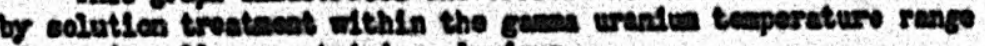
of uranlio clloge contalning alminam.

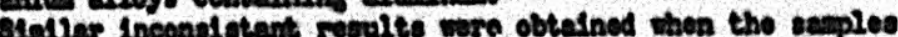
wero heated to $950^{\circ} \mathrm{C}, 2000^{\circ} \mathrm{C}$, and $1050^{\circ} \mathrm{C}$, hold $\mathrm{I}$ or varing ties at tesporatur and water quonehed.

Orenehing disy was hold between 1 and 5 eocende botween the calt beth and the guench tank. 


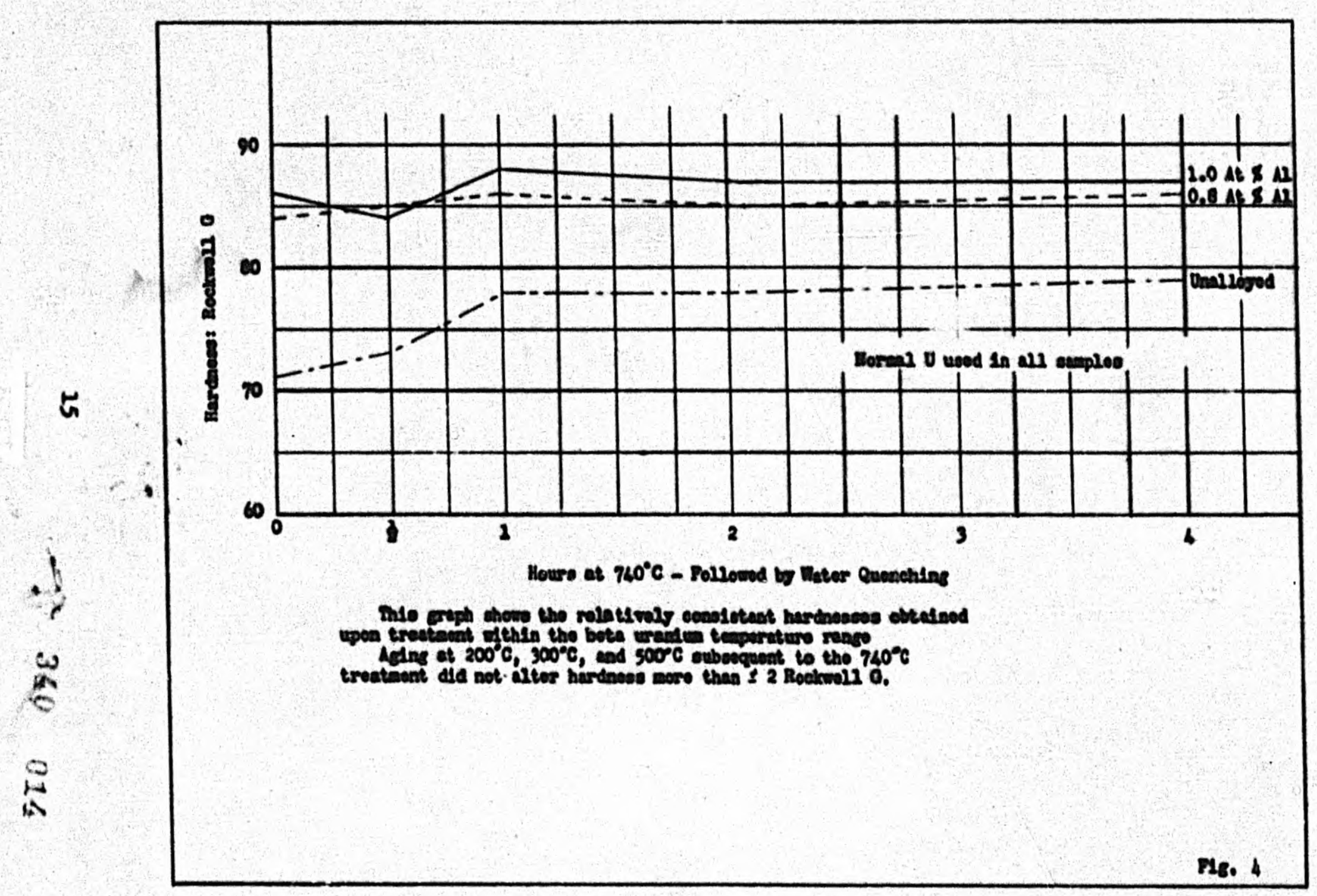


change the hardnoss of the semples teatnd.

\section{Goneral Charecteristios of Oren 1um-Aluaninum Allore}

Oranium-alualnum alloye containing more then approxinately

2.5 atomie pereont aluminum were very brittlo in the as-cest condition. This was demonstrated when samplos containing 2.9 atomis poroont alumInum oracked when stamped with 1dout ifying numbers and an as-oust tone1lo bar contsning 3.8 atom10 poroent alumines tosted 66,000 p.8.1. ultimato strongth with no appreciablo elongation or roduction in area. uleroscopio otudies of the alloy emples in the as-cast and hoat treated condition falled to Ind loato the oaisse of the orratio hardnesses obtained. Tho metallographic strueturos appeared somonthat complex and the sano atruotures appeared in both the hard and soft camplos. Typical urenium-aluminum alloy otruotures are shom in Pigure 5.

The atmosher 10 corrosion reointaneo os uraniun alloye contalning aluminum appared ape lor to unalloyed uranlum. Whohimed bare exposed to the atmosphero did not eppear to gain a dark oxido coating as rapldly as unalloyed bers.

The tened 20 propertios of com uranlum-aluminum alloye are ohown in Iablo $\pi_{0}$ Creop resistance values wore not doterninod, as it was folt that more aboirable alloye could bo obtained from other binary eystome.

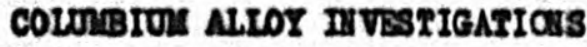

Tho columbium-uranilun alloyn which were properly melted and

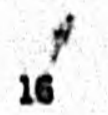

$$
340 \quad 015
$$




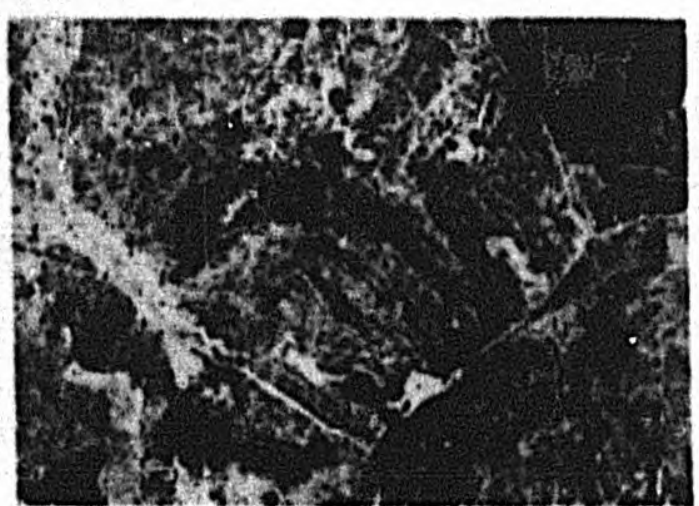

Treatments As-Cast

Average Hardness: 20 Rookwell C

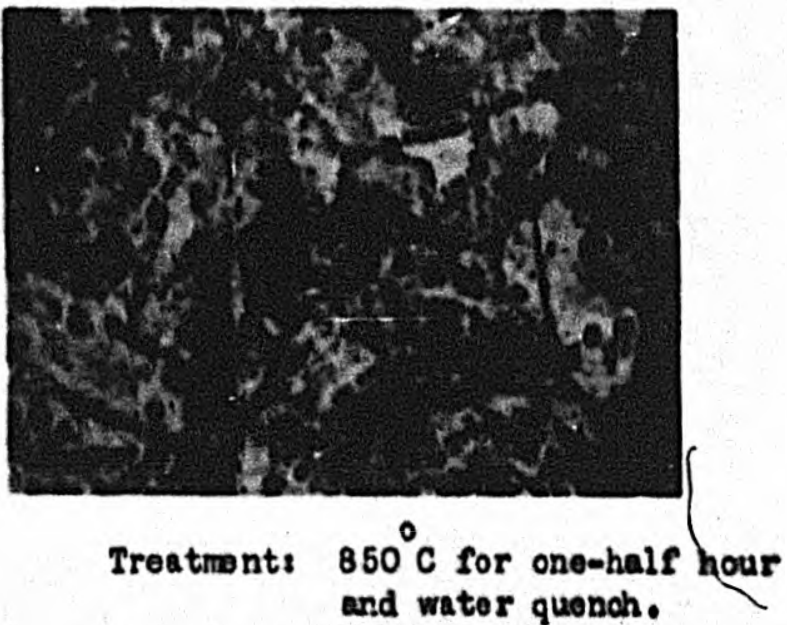

Average Hardness: 37 Rockwell C

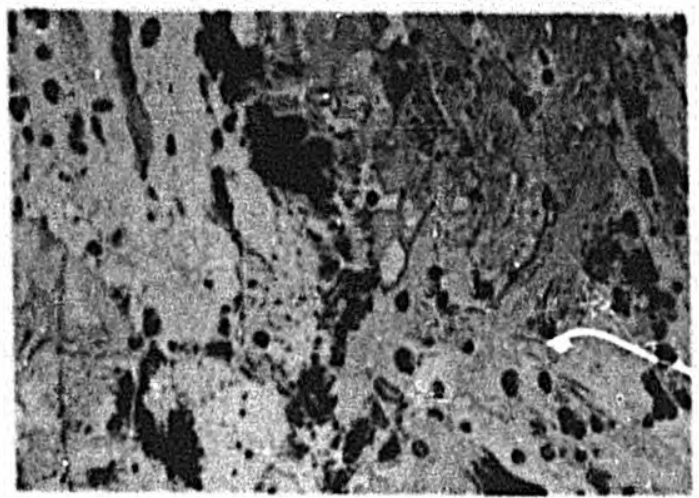

Treatmonts $850 \mathrm{C}$ for 1 hour and water quanch

Average Hardnes8: 27 Roobroll C

Figure 5i These $100 x$ Photomicrographs show the different atruotures obtained by varied treatments of samples from the sam oasting analyzing 2.5 atomic percent aluminum. The avorage hardnosses taken from the polished spocimens are given. The variad structures and orratio hardnesses shown indioate the difficulties encountered in reproducing hardness values with aluminum alloye. 


\section{TABLE I}

TEIISTLE VALUES OF URANIOU-ALURINUM ALLOYS

\begin{tabular}{|c|c|c|c|c|c|c|}
\hline $\begin{array}{l}\text { Helt } \\
\text { Ho. }\end{array}$ & $\begin{array}{l}\text { Analysis: } \\
\text { at } \% \text { AI }\end{array}$ & $\begin{array}{l}\text { Treatmont } \\
\text { See (1) }\end{array}$ & $\begin{array}{l}\text { Ultimato } \\
\text { Str. pol }\end{array}$ & $\begin{array}{c}\text { Yiold } \\
\text { Str. pal } \\
\end{array}$ & $\begin{array}{l}\text { Elong. } \\
\text { 8 in 2n }\end{array}$ & R. A. \% \\
\hline 3109 & 2.1 & AB-cast & 106,700 & 40,000 & 10.9 & 9.8 \\
\hline 3109 & 2.1 & - & 103,750 & 49,000 & 4.7 & 3.2 \\
\hline 7125 & 2.4 & As-cast & 89,400 & 42,500 & 3.1 & 2.8 \\
\hline 3126 & 2.2 & As-cest & 98,000 & 46,500 & 3.1 & 2.8 \\
\hline 4125 & 3.8 & As-cast & 56,600 & 55,000 & 0.4 & $0.4(2)$ \\
\hline 4126 & 3.8 & a & 22,550 & - & - & \\
\hline 4126 & 3.8 & b & Bar fraot & - d under & itial & (2) \\
\hline
\end{tabular}

(2) Hoat treatmonts

a. $740^{\circ} \mathrm{C}$ for $1 \frac{2}{2}$ hours and water que nohed

bo $1000^{\circ} \mathrm{C}$ for 2 hours and water quenched

(2) Brittle fractures 
cast had tensile and oreep resistance propertios considerably superior to unalloyed uranium. These alloye had a fine grain structure with reproducible hardnesses, elovated yield strength, high duotility, and increased resistance to creep in both the as-cast and heat troated conditions. However, the alloy was affrioult to propare by the usual uranium miting and oasting procedures and considorable investigative work to discover the best alloying techniques was necessary. The first uranlum-columbium alloy castings wore mado by adding 60 mosh columbium powder to the uranium charge, heating the mixture to $1300^{\circ} \mathrm{C}$ for from $1 / 2$ to $3 / 4$ hour, and pouring the metal Into a coramio lined graphito bar mold. A fer of the oastings so produced were accoptable for investigative wrk, but analysis of the castings generally showed wide variances from the columblum content desired, and fracture of the alloy bars often showed shrinkage defsots.

\section{Uranium-Columbium Alloy Molting Difrioultios}

The Inability to control the analysis of the alloy oactings was shown oarly in the program to be due to diffioulties in gaining positive solution of the columbium in the uranium. In many cases less than half of the oslumblum added to the chargo had boen taken into solution in the uranium. As is shown by the uranium-columbium phase diagrem (2), the metals are infinitely soluble in both the 11quid and high temperature gamma solid phases. The 11quidus shows a continuous curvo between the melting points of uranium $\left(1130^{\circ} \mathrm{C}\right)$ and columbium $\left(2415^{\circ} \mathrm{C}\right)$. On the basis of these data, it was considered adrisable to 
to ralse the melt temperature and hold the melt for a longer time in order to gain more complete solution of the columbium. A fow molto were made where the temperature was raised to es high as $1550^{\circ} \mathrm{C}$ and held at temperature for from 1 to 2 hours. Welts held at temperatures above $1450^{\circ} \mathrm{C}$ were rarely successfully poured due to stopper rod fallure. Attack of the magnesia crucible, stopper rod and surnace insulation was severe at temperatures above $1450^{\circ} \mathrm{C}$. Both magnesia and magnesium motal wore heavily condensed on the furnace sholl subsequent to a high temporature run and upon exposure to air the magnesium would slash and burn in a hasardous fashion,

A variety of orucible materials, less subject to break down under vacuum conditions than magnesia, were tried in order to elevate the alloy homogenization temperature. High temperature molts woro made in small cruoiblea of oerium sulfide, beryllia, sirconia, and siroco. The latter two materials showed the most promise as they withstood tomperatures of $2576^{\circ} \mathrm{C}$ for $2 \frac{1}{9}$ hours without visible sign of attack. Howovor, ohemioal analysis of the alloy slugs molted in the zirconin and 2ircon crucibles indicated a silioon (120-500 ppm respectively) and Iron (40-110 ppm respectively) piokup.

Alloy molts were made In magnesia oruoibles under partial prossures of hol fum and argon in an attempt to mininize the magnesia attaok at elevated homogenizl.ng temperatures. It was found that maltinf under inert gas partial pressure (2-6 inches of meroury) successfully minimized magnesia oruelble attack at temperatures up to $1480^{\circ} \mathrm{C}$. 
However the inert gas caused conduction and oonvection heat losses which limited operating tomperatures to $1480^{\circ} \mathrm{C}$. Analysis of the oastIngs showed that less of the columblum was dissolvod during these molts under partial pressure than with comparable melts utilising vacuum tochniques. The reluetance of the columbium to dissolve was belleved to be Increased by tho lack of outgassing agitation within molts made undor partial pressures.

It was thought that tine analys is of final castings might bo controiled by romolting alloyed stock in which the wolghts of motal had beon sdjusted acoording to the analyzed columbium content to yzold a casting of the desired analysis. Without excoption, the analysis of the final casting was orratio due, probably, to the undiseolved columblum powder trapped in the metal, the slotation of the columbium (a phenomena wich will be doscribed later), and tho inablility to obtain a truly representative samplo.

In order to lower the temper atures required for solution of the columbium, a sintered compact of uranium and columbium powders was tried as a means of introducing the columbium to the molt. The compact contained twolve atomio peroont columbium which should have a molting point of approximate ly $1350^{\circ} \mathrm{C}$ (Interpolated from the phase diagram) if the compact was completely homogenized. The sintered compacts only partially dissolved in the uranium motal then held at $1400^{\circ} \mathrm{C}$ for one and a half hours. After the molt was poured, the master alloy compacts retained in the onioible appeared to have been differentially leached. 
An attempt was made to make a master alloy of oolumblum and nickel in which the nickel was used as a carrier for the columblum to gain low temperature solution of columblum in uranium. The charge contained 40 atomic percent columbium and remaindor nickel, which oonfoms with outetic composition melting at $1175^{\circ} \mathrm{C}(6)$. The eutetio contains $\mathrm{N}_{3} \mathrm{Cb}$ as one of the phases and it was hoped that the presenoe of tho intermetallio compound would alloy brittlo fracture of the master alloy. Such a physioal condition of the alloy would faollitate making the charge and afford a large surface area for solution in the melt. After molting the master alloy, the magnesia crucible showed severo attack beneath the metal surface. The resulting olloy was hard and did not yleld to ready fracture. Work with the nickel-columbium master alloy was oarried no nurther as it was folt that the physical oharacteristios were not dosirable and the composition of the master alloy would be difficult to control. In addition, the use of nickel would lower the purity of the uranium alloy and could alter the properties of the alloy in an undesirable fashion.

The most satisfactory method of making a columbium alloy addition to urantum was found to be with columbium-uraniun alloy buttons prepared in the reduction bomb. Alloy buttons containing $1.5,5$, and 10 atomic peroent columbium in uranium were propared by Benjamin $R$. Hayward and these butt cis have been used as master alloy additions for both experimental and production castings. The alloy buttons were made by adding oither columbium powdered metal or $\mathrm{Cb}_{2} \mathrm{O}_{5}$ to the standard 
reduction charge. Reference lo made to LA 472, Proparation of Uranium Wetal by 8 tationary Bomb Wethod by R. D. Baker and a report now in the process of preparation by Hayward on the bomb production of columbiurauraniva master alloy buttons. The master alloy in all oomposition ranges was readily soluble in uranium when held at $2350^{\circ} \mathrm{C}$ sor one-half hour. The final compositions of the alloy castings could bo held within $\$ 0.25$ atomle percent whe $n$ the master alloy bisoults were used,

The flotation of columbium in alloyed mats, which has been previously montioned, was indicated by ohemical analyols of number of alloy melts. Then sluge of alloy were seotloned and analyzed aubsequent to freesing in the o rueible the upper portions of the ingot generally contalned greater unounts of columbium and carbon. Columblum coneentrations at the top of the cesting ocourred also in large statio oast ohapes where the metal was poured at a sufficient temperature to cause a delay In the freesing of the malal after pouring. Centringally oast shapes consistently showed a higher columblum and carbon ocntent in the center of the castinge, Indicating that the top of the melt or the last metel poured contalned a columbium coneentration. The tendency for the flotation of columbium was more pronounoed in molts made with normal urenilum containing 100-500 ppn. of carbon than when high purity cort ain ing 30100 ppm of carbon was used. This phenomena was not completely invo st1gated but sufficient data here been collected to indicste the oause. The consistent relationship between high carbon content with $h / g h$ columblum content and machining difficul ti ea encountered in areas of 
alloy concentration Indicated the presence of herd carbides. It is bolleved that columblum, whon added to aranium oharge containing appreolable oarbon, conbined to fom either a solumbium carblde or poselbly a complex columblum-uranium carbide upon heating of the oharge and tended to riee within the molt. Mloroscopio studies have shown a concentration of carbides in the hifh columblum content regions, but these oarbides have the physical appearance of uranlum carbide. The flotation of the columbium con best be controlled by the use of low oarbon miting stook.

\section{Uranium-Columblum Casting Diffioultien}

Lost of the early castings produced for tenslle teste of columbium-uranlum alloys were defeotlve due to shrinkage cavitien withIn the tensile bars. The bar stock had been cast in the same manner that tenaile bars for uranium had been made in the past. The motal was cast into an Alundum lined graphite mold to yleld a I inch diamoter bar, 6 Inohes long and headed at one end with a large dlameter feeder head. In the past, no defects were noticeable in uranlum tensile bars cast In this rashion, but columblum alloy bars oast in this type mold had 10w duotility and a shiny, spongy area was generally rovealed at the tensile sracture surface. The spongy areas apposed and were at first thought to be regions of undiseolved colunbiun powder. A typleal shing dofeot in a fractured tensile bar is shown in Figures 6 and 7. These spongy regions wore often not datectablo by radiographio inapection of the bars prior to tensile testing. Chemical analysis of the shiny 


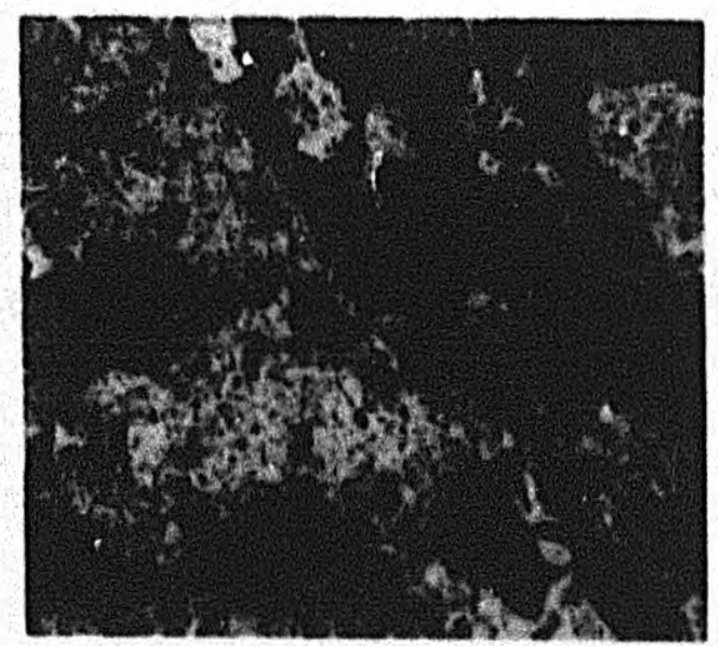

Figure 6: This $100 \mathrm{X}$ photonlorograph shows an area of shrinkage defects in an alloy bar containing 2.5 atomic percent columblum. This type of defect is also shom in a macrophoto in Figure 6. This defect comonly occurred along the central axis of columbiun alloy cast bars. Such a defect has never been noted in unilloyed uranium bara cast in the eame mannor. 


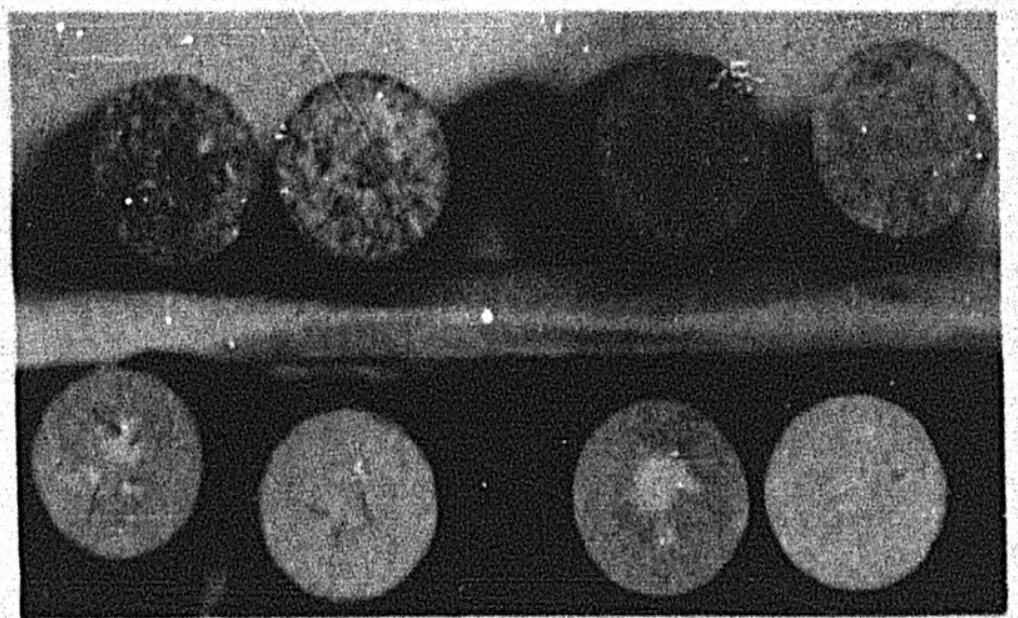

F1gure 7t Thls macrophotograph thow the fracture ourface of four standard 0.505 Inch tensile bars. The bar on the right of each pasr has boen brightened by dipplng in a nitrio acid bath. The bare in the top row contaln 0.9 atomio percent coluesbitus the pairs in the bottor row contain 1.5 atoalo percent columbium. Pairs on the left are in the esecast conditi an and paira on the right have been solution treated at $860^{\circ} \mathrm{C}$ for $1 \frac{2}{2}$ hours, followed by a water quenoh, and aged at $350^{\circ} \mathrm{C}$ for threo houra and furmace cooled. The large grain 8180 of the 0.9 atomie percent oolumblum alloy in the as-oast condition and the sall aise of the treated specimon is shown. The shing areas of the 1.5 atonde peroent allojs are chrinkage defects, also show in Pigure 5. 
regions falled to show high columblum content and the regions wero Later proven to be osused by shrinkage. Tapered bars wero cast to proFide progressive solidifiention within tho bar castinge, but the dofective regions also occurred in the tapered castings. The problem was overeome by oasting brioks $2 \frac{1}{4}$ inches by $2 \frac{1}{4}$ Inches by 6 inches long toppod with an adequate foeder head. Bach briak cesting was soctioned through the vertical axis into four square bars. Any shrinkage carlties oceurring in the brick were 1 imited to the central axie region and eliminated by the saw suts or subsequent machining of the bars to size. It was felt that tensile bars out from brick castings more nearly represented the metal which would be achieved in a production casting, as the mase of the brick was closer to the mass of a nornal oasting and the cooling rates could be more olosely related.

\section{Heat Treating Provedures for Uranfum-Columblun Alloys}

Although the physical proporties of the columblum-uranium alloys were considerably higher then unalloyed uranium in the as-cast condition, heat treatment of alloyed bars was investigated to deternino what adventages might be gained. It was found that colunbiun alloys were highly responsive to heat treatment and that $h i$ gher streng the and hardnesses could be obtained with only slight loas of duotility. The heat treatnents Investigated wero based on procedures reported by Sawyer (4). Comparative date for as-cest and heat-trekted bars are ohown in Table II. 


\section{TABLE II}

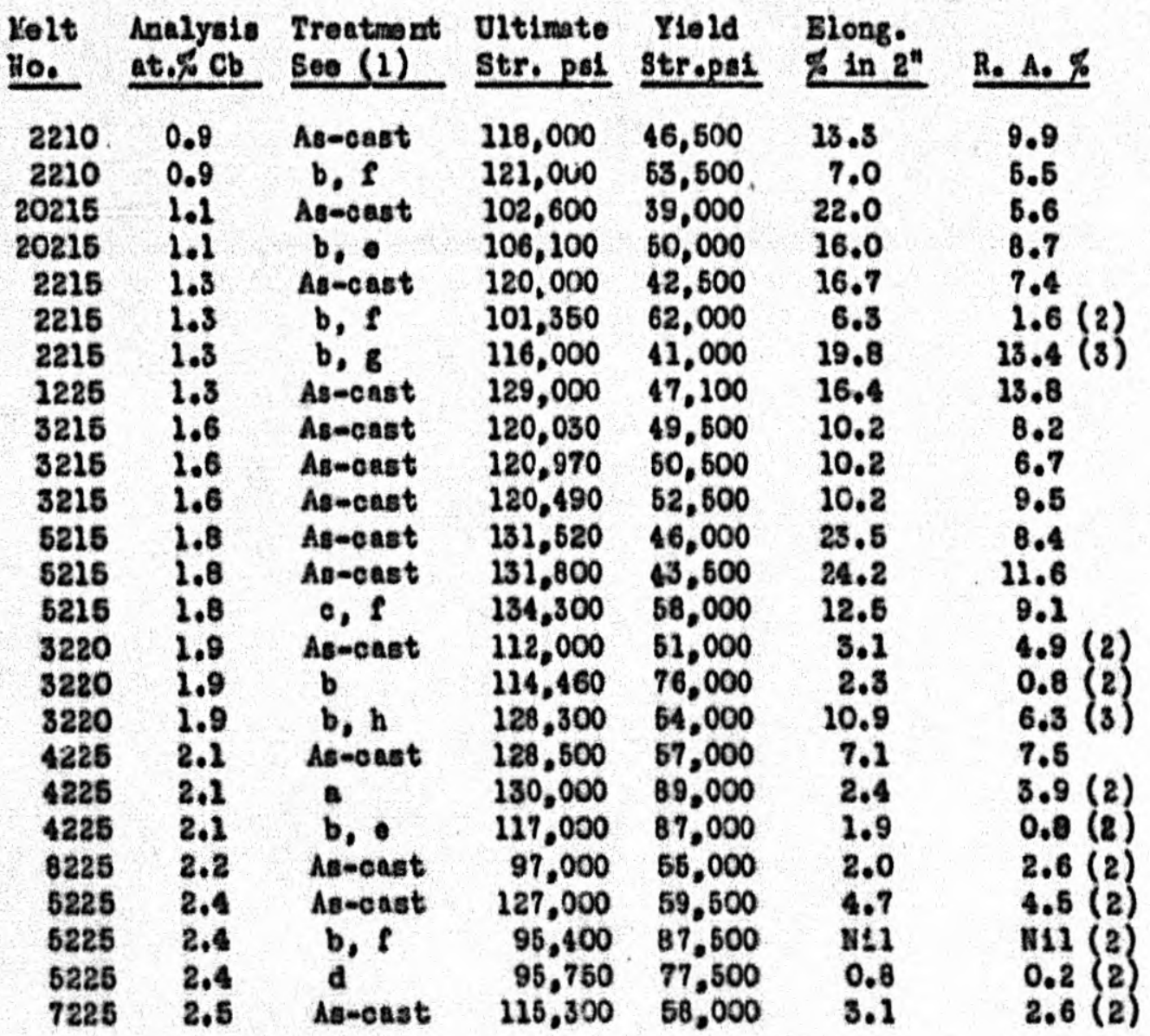

(1) Special Trestments: a. Cast bar cold worked by pressing

b. $850^{\circ} \mathrm{C}$ for $1 \frac{\mathrm{g}}{\mathrm{g}}$ hours and water quenched

c. $800^{\circ} \mathrm{C}$ for $1 \frac{1}{8}$ hours and water quenched

d. $700^{\mathrm{C}}$ for $1 \frac{1}{2}$ hours and water quenched

- $350^{\circ} \mathrm{C}$ for $1 \frac{2}{2}$ to 2 hours and furnace cooled

f. $350^{\circ} \mathrm{C}$ for 2 to 4 hours and furnace cooled

5. $600^{\circ} \mathrm{C}$ for $1 \frac{1}{\mathrm{e}}$ hours and furnace cooled

h. $600^{\circ} \mathrm{C}$ for 5 hours and furnace cooled

(2) Tensile bar frectures showed shrinkage defoets causing reduoed ductility.

(3) These tensile reaults indicate over aging. 
Alloyed bars containing from $0 . \$$ to 3.5 atomic percent columbium were hold for varyling times at 700,800 and $850^{\circ} \mathrm{C}$ and quenched. The quenched bars were eged at $350^{\circ} \mathrm{C}$ for from $2 \frac{1}{\mathrm{a}}$ hours to 4 houro followed by surnace cooling. Hardnosses and tensile tests indierted the most satis factory treatme nt for columbium alloyed bars within the composition and $01_{2} 0$ ranges investigated was as follows heating at $8 E 0^{\circ} \mathrm{C}$ for 1 $\frac{1}{2}$ hours followed by a water quench, and ag ing at $350^{\circ} \mathrm{C}$ for two hours with sample cooled in the furnace.

Tests were conduoted on a Jominy end quanch opocimen of a 1.35 atomlo percent columbium alloy to indicate the effeotive depth of a water quench subsequent to $1 \frac{1}{2}$ hours at $850^{\circ} \mathrm{C}$. High hardness was obtalned within one-half inch of the quenched end and moderately erfoctive hardening with $1 \mathrm{~s} / 4$ inch of the quenched end, as ahown in Figure 8. Figure 9 shows the hardness results for a Jominy end quenoh of an aluminum-uranium alloy bar.

\section{Characteristios of Uranium-Columbium Alloys}

Alloys containing greater then approximately 1.0 atomlo percent columbium had a fine grained strueture, as shom in Figuren 7 and 10. One bar casting which analysed 0.9 atonic peroent columblum and all castings examined which analyzed less than 0.9 atomic porcent oolumbium had comparatively coarse grained struetures in the asmesst condition. There was indication that alloys contalning 0.9 atomle porcent columblum were grain refingd by treatment with in the geme-uranlum 


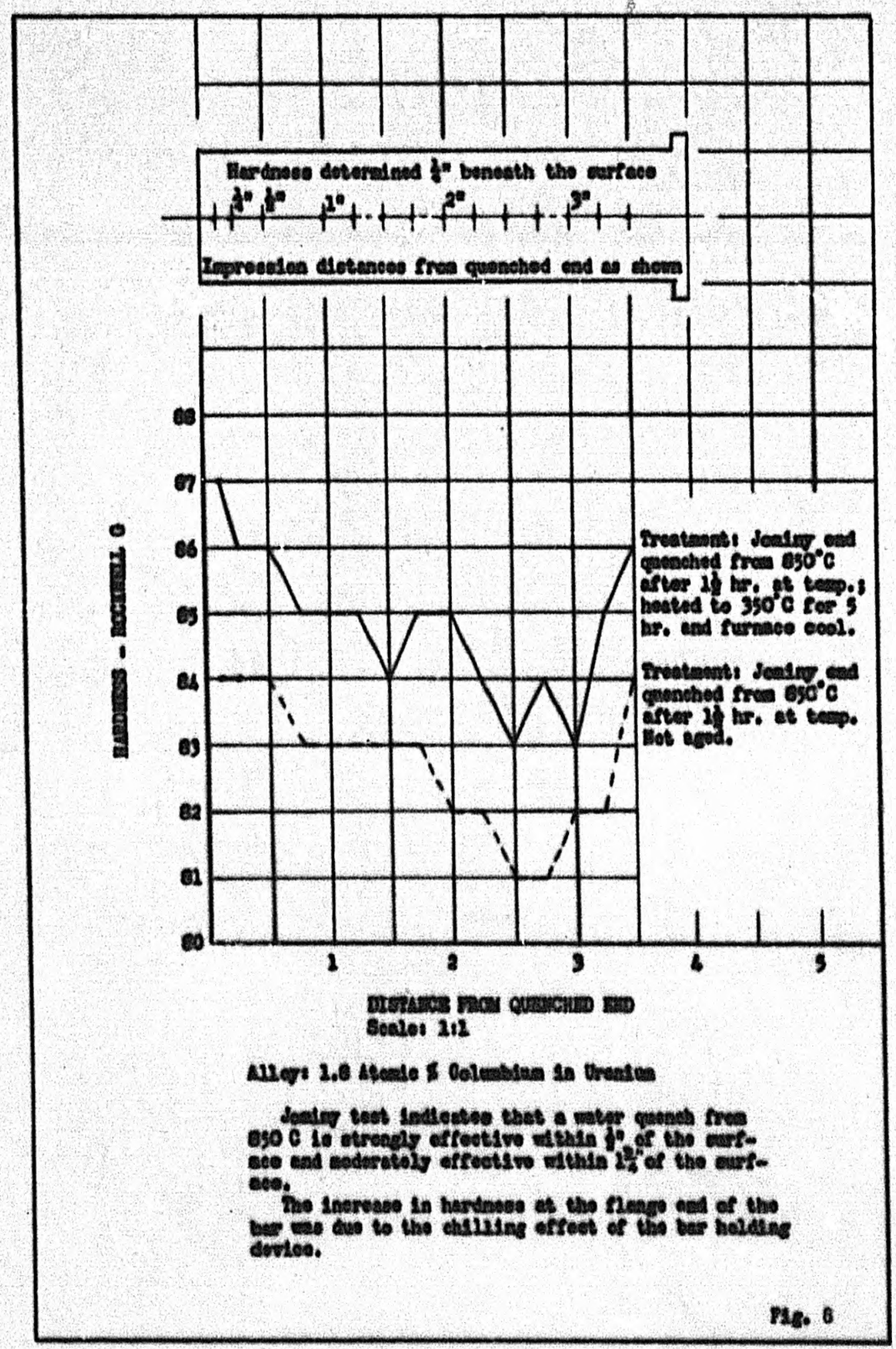




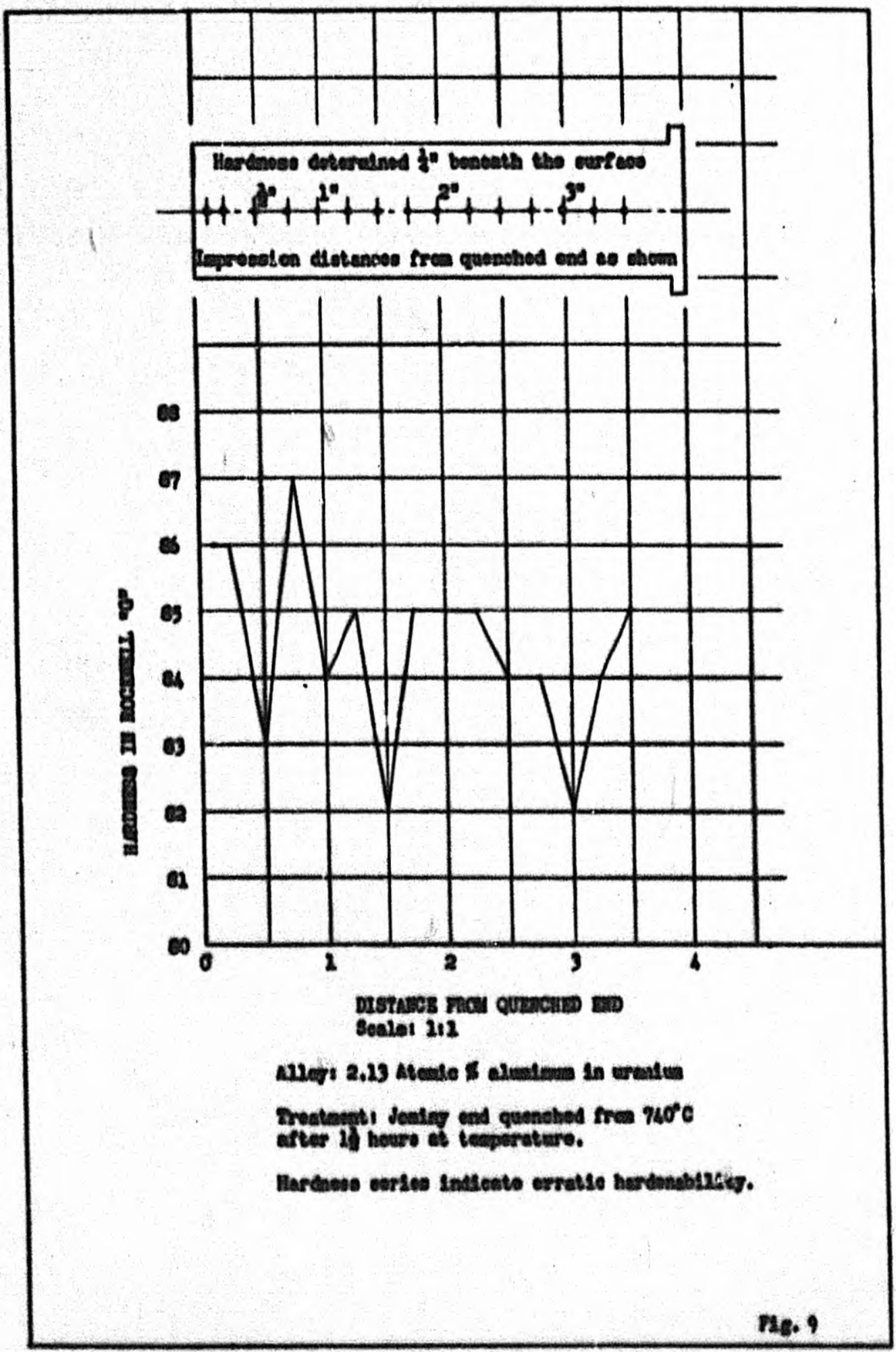

$31 \quad 340 \times 0$ 


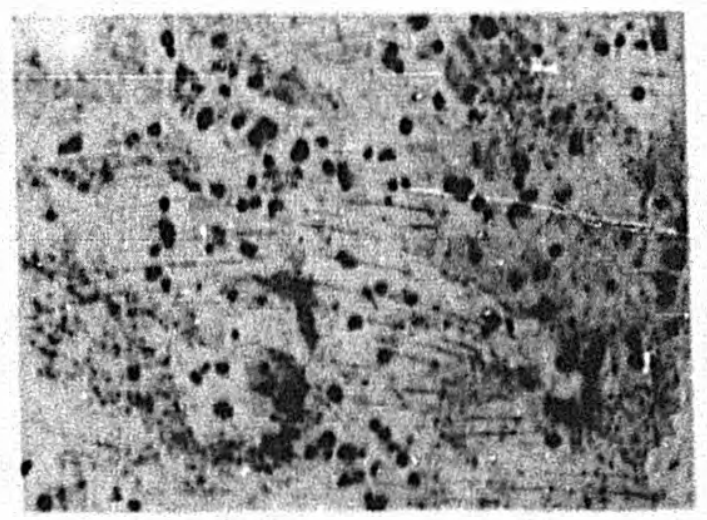

TREATMENT: As-cast

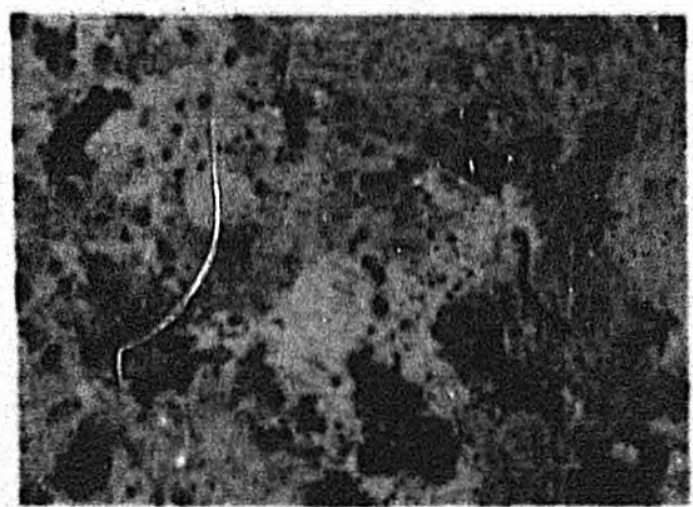

TRFATMENT, $850^{\circ} \mathrm{C}$ for one and one half hours and water quenoo.

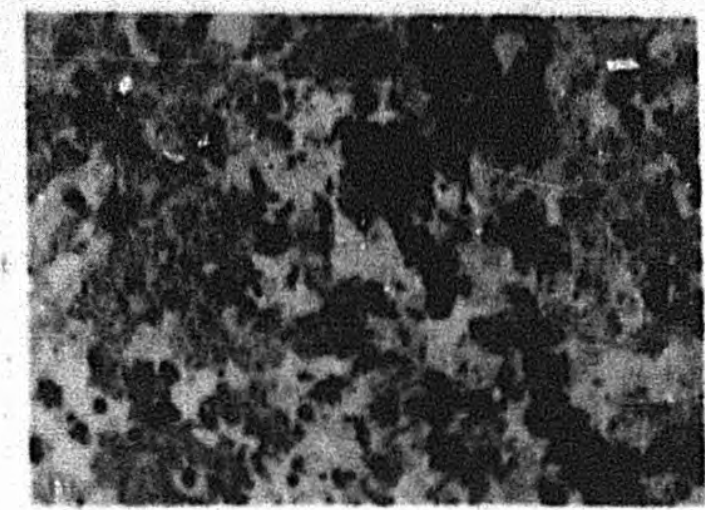

TREATWNT, $850^{\circ} \mathrm{C}$ for one and one half hours and water quence.

$350^{\circ} \mathrm{C}$ for two and ona half hours and water quench.

Figure 10s These $100 \mathrm{X}$ photomicrographs show structures obteined from three samples of the sane casting analysing 2.2 atomic percent columbium. The bars were subjected to the different treatments as given above. Although the struotures appear sinilar, investigationa tave show that the hardnessea and yleld otrongthe of these alloys inerease with the heat treatinents given above. 


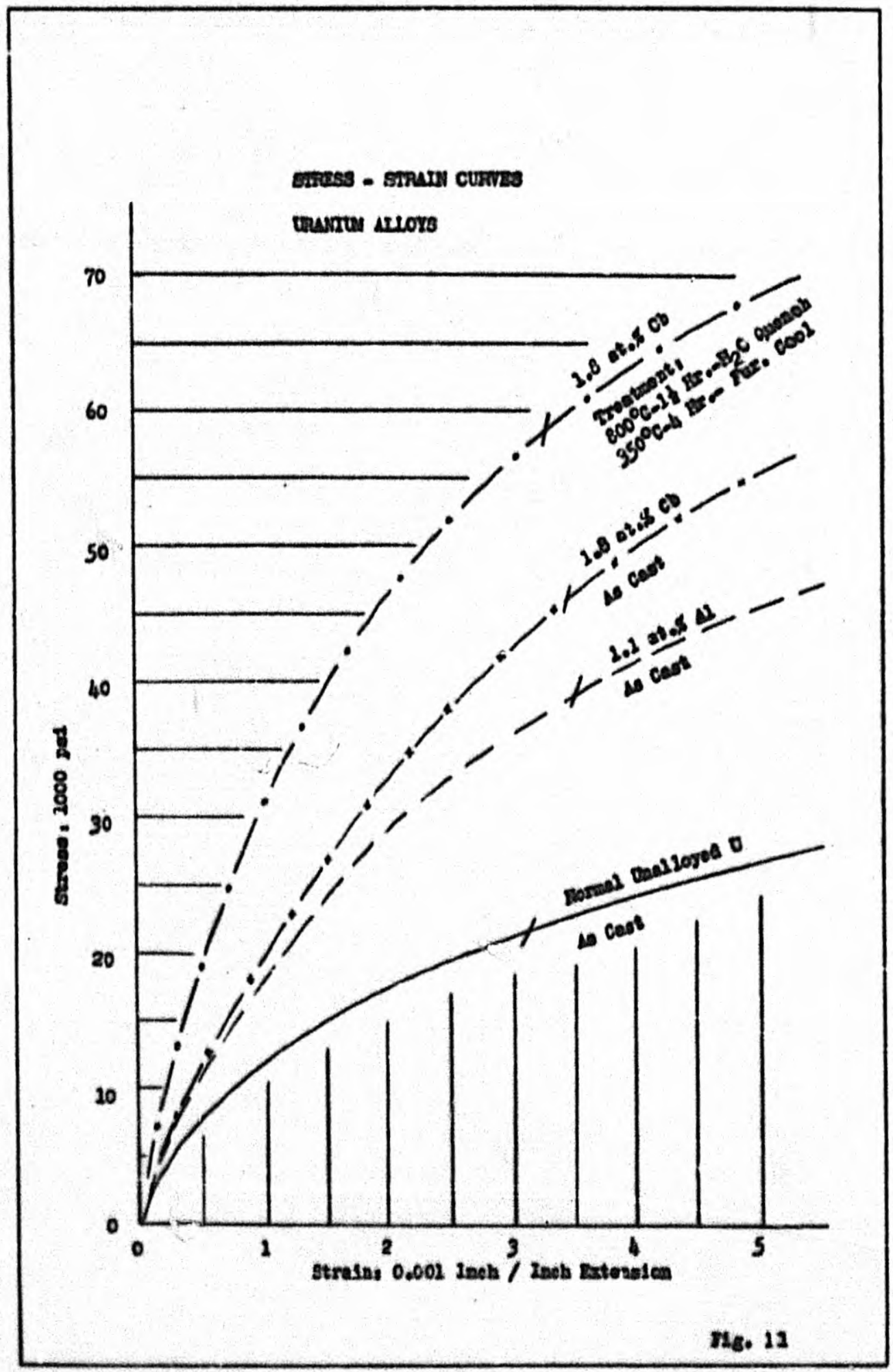

33

$340 \quad 012$ 
teape rature range.

Tenalle testa of sound bara revealed high phyaloal properties.

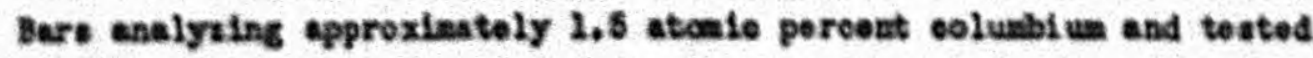
In the as-east condition averaged 125,000 pai ultinate atrength, 45,000 poi yiold strength $(0.26$ orruet). $20 \%$ elongation in a 2-inch gauge length, and $8 \%$ roduetion in srea. These values should be osmared with properties reported by D. $T$. Doll (7) In teots condueted on unalloyed high purity uranium were values of 71,890 pal tons 11 s strength, 28,000 pol yle1d strength $(0.2 \%$ of foet $), 6.25 \%$ elongation in two inches and 3.316 reduetion in area were found, and tensile propertios for unalloyod uranitue thown in Figure 11.

An inorease in the amount of ooluablum, in wo far ese explored In this prograx, eppesed to further ineresse the yleld strength with a los in duotility. Heat trentment et $850^{\circ} \mathrm{C}$ with ecting at $350^{\circ} \mathrm{C}$ also ralsed the tenalle properties of the metal.

Creep test vilus of columblum alloys in both the as-cest and hest trostod condition are presented in Tablo III. Creop data on unalloyed uranium samples are wow for purposes of compartson.

Columblua additions appeared to increase the corros ion reaistance of urenius, but not to a groat en oxtent va aluminus additions. Machined samples of columblua alloy did not form dark oxd do contings as rapidly as unalloyed urentum. 


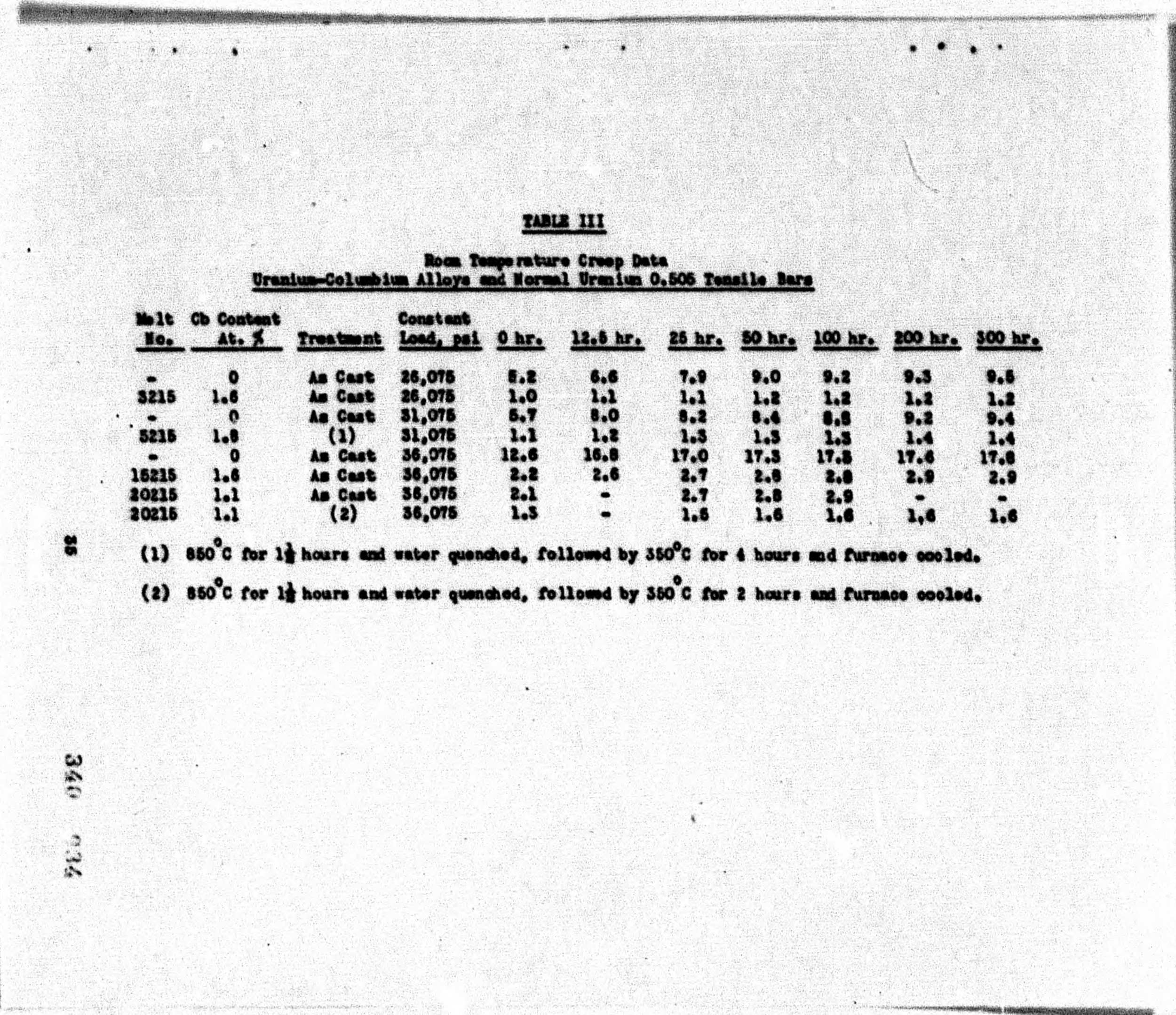
Helt co Content
Ho. At. $\mathrm{I}$ 


\section{coscurstors}

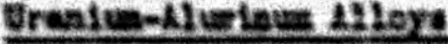

1. It is difrteuls to cehitev the deatred enelyols is a wreatue-

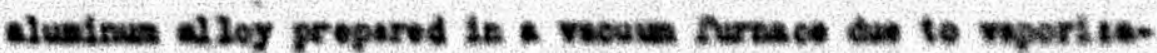
tlon losaes of aliatnuas.

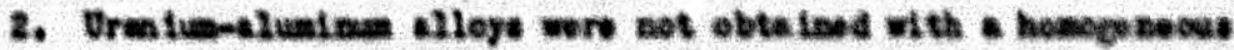
cluniem dietribution, os is chom by widely varying walyest betwen the top and bottos seetione of earting.

3. Aluaina alloys did not rospond uniformily to hest troetwent. Conalderable varinti ch in hardnessen was obtained upos oelution trooting in the cocme range. Solution treating in the

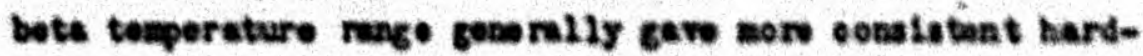
nosses but not a curfielent Inerease in phyeleal propertios

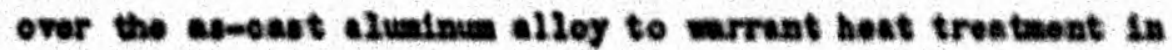
this range.

4. Phyoleal propertios, highor than thoee of unalloyed uranites, wore obtalned with olualnu elloye but the raluen wore orretie and diffieult to reprodues tue to alting probleas.

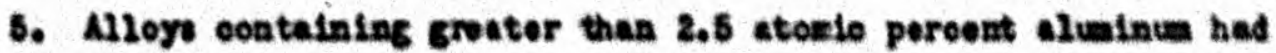
Low duotility In the al-cost and eolution treetod conditions.

6. Tho atomonpherlo corrosion roulatance of al uninum alloye in the aluinin contont ranges investigated eppeared to bo euperior to elther colubilu elloye or unalloyed uraniven. 


\section{Eraste-celodice Alies}

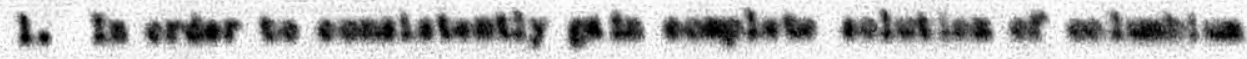

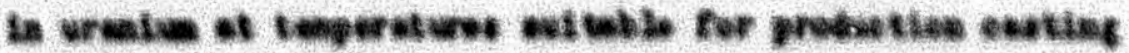

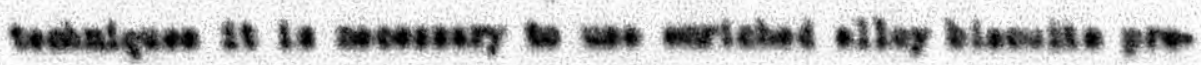
pared ti * ndaeti ee hoeb.

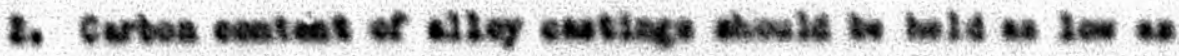
posible of it the bees bees that the presenes of exrbe

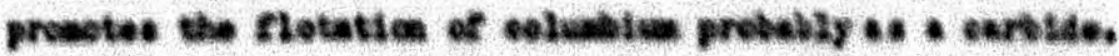

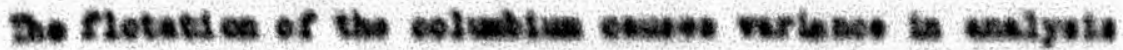
throughent the enoting ed mehisize cifrieutties.

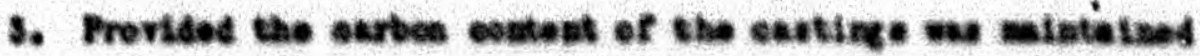

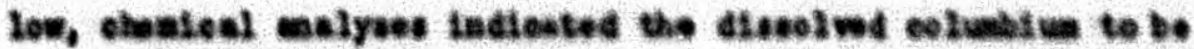
owaly diotributed with the east alleg. Herdean values

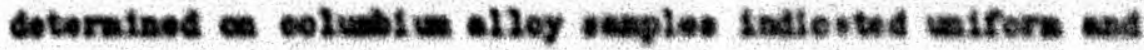
repreduetble herdeweses.

4. To obtaln teasile and ereep speeinene free troe internal Hribkage defeots, It wes found woesenry te east a briek shape thich oubeequently seetioned through the vortienl exis to ylold the required bers.

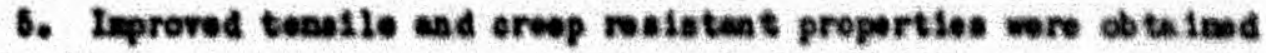

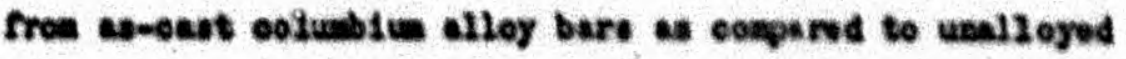
uranivan.

6. To oolumblia alloy bers reapoeded to host trestant by showing olovated ylold otrongtho. 


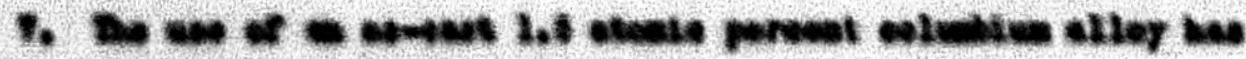

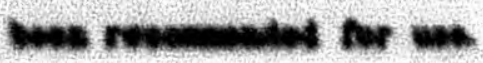

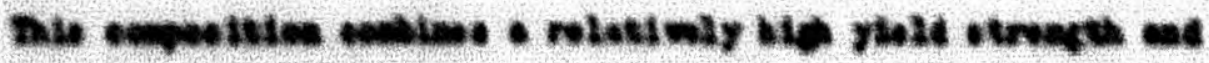

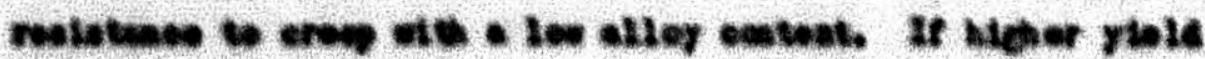

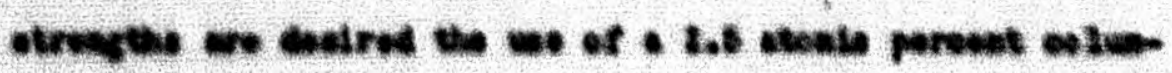

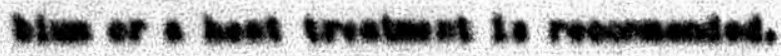




\section{ermiogusis}

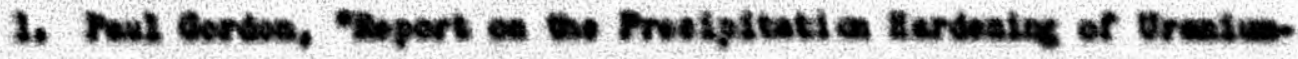

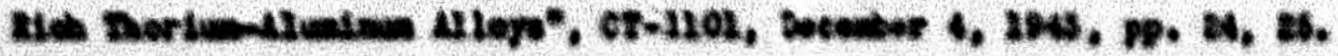

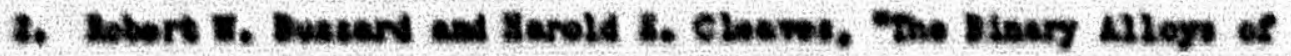

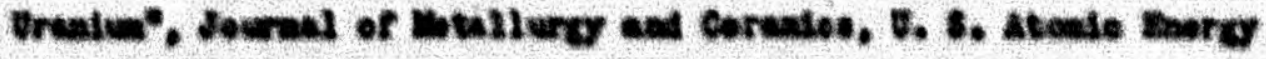

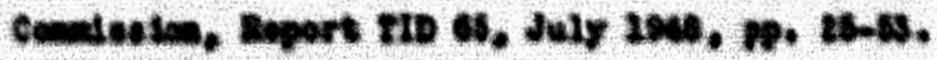

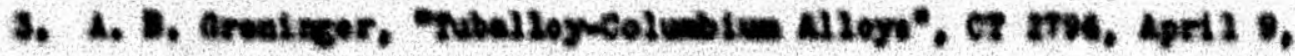
14s, n. 6-20.

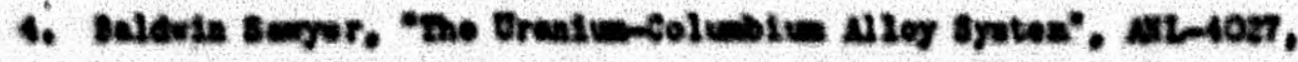
Oetober 1, ING.

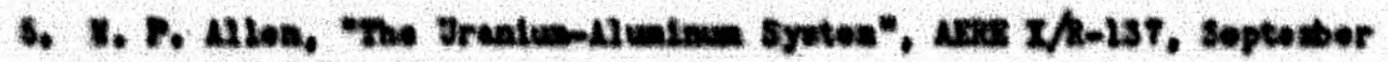
3. 244.

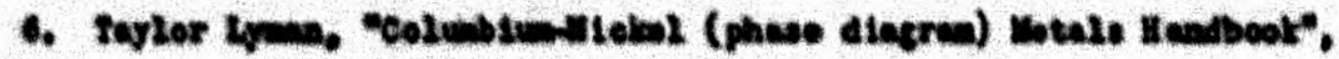
Lerieca sentoty tor votale, Ies Eation, po IIt?.

1. D. ז. Doll, Toall Date, ALh Nurlty tubelloy, Roport to J. C. Potts, Anguat 9,1 \%9. 


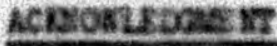

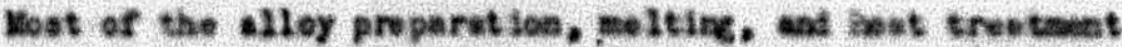

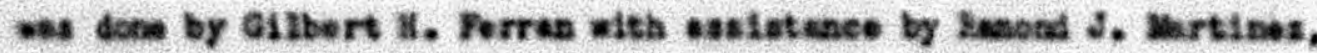

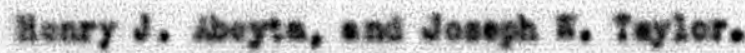

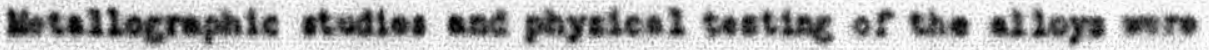

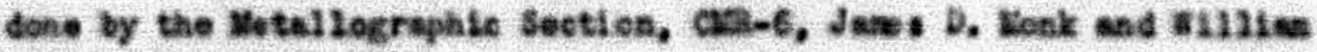

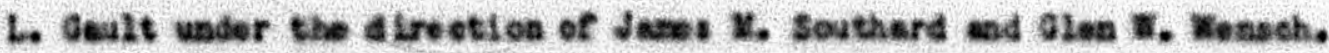
Grophite solds were menibed by the Srephite Shop weder the

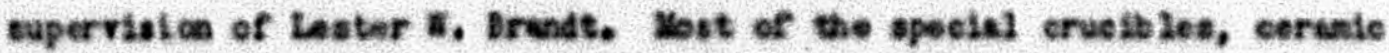
nold Inserts, and ald costings were nde by the Cereates Seetica, Cxi-6 under Mdrian 0. A131een.

Chenied andyals ws done by Group cke-1 under the direction

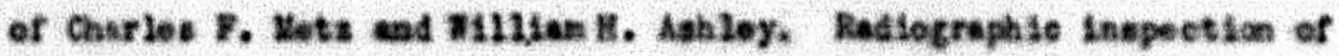
the eastings ws dobe by Gax-1 under Cerold H. Penney. 